\title{
Developmental Regulation, Expression, and Apoptotic Potential of Galectin-9, a $\beta$-Galactoside Binding Lectin
}

\author{
Jun Wada, ${ }^{\star}$ Kosuke Ota, ${ }^{\star}$ Anil Kumar, ${ }^{\star}$ Elisabeth I. Wallner, ${ }^{\ddagger}$ and Yashpal S. Kanwar* \\ $*$ Department of Pathology, and ${ }^{\ddagger}$ Department of Medicine, Northwestern University Medical School, Chicago, Illinois 60611
}

\begin{abstract}
Galectin-9, a $\beta$-galactoside binding lectin, has recently been isolated from murine embryonic kidney. In this study, its biological functions and expression in embryonic, newborn, and adult mice tissues were investigated. By Northern blot analyses, it was found widely distributed and its expression was developmentally regulated. In situ hybridization studies revealed an accentuated expression of galectin-9 in liver and thymus of embryonic mice. In postnatal mice, antigalectin-9 immunoreactivity was observed in various tissues, including thymic epithelial cells. The high expression of galectin-9 in the thymus led us to investigate its role in the clonal deletion of thymocytes. Fusion proteins were generated, which retained lactose-binding activity like the endogenous galectin-9. Galectin-9, at $2.5 \mu \mathrm{M}$ concentration, induced apoptosis in $\sim 30 \%$ of the thymocytes, as assessed by terminal deoxytransferase-mediated dUTP nick end labeling method. The apoptotic effect was dose dependent and lactose inhibitable. At higher concentrations, it induced homotypic aggregation of the thymocytes. Electron microscopy revealed $\sim 60 \%$ of the thymocytes undergoing apoptosis in the presence of galectin-9. By immunofluorescence microscopy, some of the thymocytes undergoing apoptosis had plasmalemmal bound galectin-9. Galectin-9 failed to induce apoptosis in hepatocytes. Taken together, these findings indicate that galectin-9, a developmentally regulated lectin, plays a role in thymocyte-epithelial interactions relevant to the biology of the thymus. (J. Clin. Invest. 1997. 99:24522461.) Key words: galectin • thymocytes • apoptosis • development • kidney
\end{abstract}

\section{Introduction}

Specific interactions between carbohydrate moieties and their putative binding proteins (i.e., lectins) play a critical role in various developmental, physiological, and pathologic processes (1). Mammalian lectins are classified into four categories, C-type lectins (including selectins), P-type lectins, pentraxins, and galectins $(2,3)$. Galectins seem to be highly conserved, since they have been found in animals low in the evolutionary phylogeny, including poriferans and nematodes

Address correspondence to Yashpal S. Kanwar, Department of Pathology, Northwestern University Medical School, 303 E. Chicago Ave., Chicago, IL 60611. Phone: 312-503-0084; FAX: 312-503-0627.

Received for publication 20 December 1996 and accepted in revised form 5 March 1997.

J. Clin. Invest.

(C) The American Society for Clinical Investigation, Inc. 0021-9738/97/05/2452/10 \$2.00

Volume 99, Number 10, May 1997, 2452-2461
$(4,5)$. To date, 10 members of lactose binding mammalian galectins have been cloned, sequenced, and functionally characterized, and they include galectin-1 (6), -2 (7), -3 (8), -4 (9), -5 (10), -6 (10), -7 (11, 12), -8 (13), -9 (14), and -10 (15-17). Galectin-9 has two carbohydrate binding domains, which are structurally related to galectin- 4 and -8 . The carbohydrate binding domains are connected by a link peptide. Interestingly, a long splicing isoform of galectin-9, exclusively expressed in the small intestine, has a 31 amino acid insertion between the $\mathrm{NH}_{2}$-terminal carbohydrate binding domain and its link peptide (14).

Like other mammalian lectins, the galectins have been implicated in diverse biological processes, including modulation of cell-cell and cell-matrix interactions. Among the various galectins, galectin-1 and -3 have been well studied. Galectin-1 has been shown to bind with laminin and to inhibit cell-matrix interactions (18), which are mediated via the laminin receptor integrin $\alpha_{7} \beta_{1}(19)$. Galectin-1 also plays a role in cell proliferation (20), cell migration (21), immunologic modulation and apoptosis in PHA-stimulated peripheral $\mathrm{T}$ cells $(22,23)$, carcinogenesis (24), and embryogenesis (25). Galectin-3 recognizes certain specific ligands (e.g., IgE, reference 26 and laminin, reference 27), and mediates a multitude of biological functions, including bacterial colonization (28), superoxide production of neutrophils (29), acting as a pre-mRNA-splicing factor (30), regulation of $\mathrm{T}$ cell growth and apoptosis (31), and carcinogenesis (32). Activity of galectin-3 is itself modulated by metalloproteinases 2 and 9 (33) and tissue-type transglutaminase (the latter is involved in cross-linking and oligomerization processes) (34). These rapidly accumulating literature data imply that the galectins are essential macromolecules that, conceivably, are relevant in diverse biological functions involving interactions of cell surface-associated saccharide chains and extracellular matrix glycoproteins.

In this investigation, some of the functional characteristics of galectin-9 were studied. The expression of galectin-9 was determined in various embryonic and adult tissues by Northern analyses, in situ hybridization, and immunofluorescence microscopy. In addition, the role of galectin-9 in thymocyteepithelial/stromal cell interactions was investigated since it was found to be highly expressed in the thymus and developmentally regulated.

\section{Methods}

Northern blot analyses. Analyses were performed on total RNA isolated from various tissues of fetal and adult ICR mice (Harlan Sprague Dawley, Inc., Indianapolis, IN), as described previously $(14,35)$. In brief, $30 \mu \mathrm{g}$ of total RNA of each organ was glyoxalated, subjected to $1 \%$ agarose gel electrophoresis, transferred to a nylon membrane (Amersham Corp., Arlington Heights, IL), and hybridized with $\left[\alpha^{32} \mathrm{P}\right] \mathrm{dCTP}$ random-radiolabeled mouse galectin-9 (U55060; Genbank/EMBL/DDBJ) and $\beta$-actin cDNAs (M62174; American Type Culture Collection, Rockville, MD) under high stringency conditions. The membranes were then washed and autoradiograms prepared. 
In situ hybridization. In situ hybridization was carried out as previously described (35). Whole mouse embryos (day 13) were fixed in $4 \%$ phosphate-buffered paraformaldehyde solution at $4^{\circ} \mathrm{C}$ for $12 \mathrm{~h}$. The organs of adult mice were harvested after intracardiac perfusion with $4 \%$ paraformaldehyde, and allowed to fix at $4^{\circ} \mathrm{C}$ for $3 \mathrm{~h}$. Tissues were embedded in paraffin, 3- $\mu$ m-thick sections prepared and mounted on RNase-free glass slides. Sections were deparaffinized, hydrated, digested with proteinase $\mathrm{K}$, treated with triethanolamineacetic anhydride, and rehydrated. Plasmid vector pBluescript KS(+) (Stratagene Inc., La Jolla, CA), containing mouse galectin-9 cDNA insert (14), was linearized by restriction enzymatic digestion with BamHI and XhoI. Antisense and sense riboprobes were synthesized by incorporating $\left[\alpha^{33} \mathrm{P}\right] \mathrm{dUTP}$ (Amersham Corp.), using T7 and T3 RNA polymerase (Promega Corp., Madison, WI). Finally, the tissue sections were hybridized with galectin- 9 riboprobe at $50^{\circ} \mathrm{C}$ for $18 \mathrm{~h}$, coated with NTB2 photographic emulsion (Eastman Kodak Co., Rochester, NY), and developed after 1-2 wk exposure.

Generation of antibody, immunoprecipitation, ELISA, Western blot analysis and immunohistochemistry. A polyclonal antibody was raised by immunizing rabbits with a synthetic peptide, KTQNFRPAHQAPMAQT; its sequence was derived from the link peptide of mouse galectin-9 (14). An additional lysine residue at the $\mathrm{NH}_{2}$-terminus was used for conjugation of the peptide to keyhole limpet hemocyanin. To assess the specificity of the antibody, immunoprecipitation, ELISA, and Western blot analyses were performed.

For immunoprecipitation experiments, newborn mouse thymuses were radiolabeled in vivo by an intraperitoneal injection of $\left[{ }^{35} \mathrm{~S}\right] \mathrm{me}-$ thionine $(50 \mu \mathrm{Ci} / \mathrm{g}$ body wt) (Amersham Corp.). After $24 \mathrm{~h}$, the thymuses were harvested, homogenized in Tris-DTT buffer (20 mM Tris, pH 7.4, $5 \mathrm{mM}$ EDTA, $150 \mathrm{mM}$ sodium chloride, $1 \mathrm{mM}$ DTT, $10 \mathrm{mM}$ benzamidine, $10 \mathrm{mM} \epsilon$-amino- $n$-caproic acid, $2 \mathrm{mM}$ phenylmethanesulfonyl fluoride, $1 \%$ Triton X-100) $(14,35)$, and sonicated. The homogenates were centrifuged at $10,000 \mathrm{~g}$ for $30 \mathrm{~min}$ at $4^{\circ} \mathrm{C}$, and the supernatants were applied to lactosyl-Sepharose columns (Sigma Chemical Co., St. Louis, MO) and eluted with $0.2 \mathrm{M}$ lactose in Tris-DTT buffer. Immunoprecipitation was performed by adding $10 \mu \mathrm{l}$ of antimouse galectin-9 antibody to $0.5 \mathrm{ml}$ of eluate, containing $\sim 0.5 \times 10^{-6} \mathrm{dpm}$. The eluate/antibody mixture was gently swirled in an orbital shaker for $18 \mathrm{~h}$. Protein A Sepharose 4B (Pharmacia LKB Biotechnology, Piscataway, NJ) was added to the antibody/galectin-9 complex and mixed for $2 \mathrm{~h}$. Subsequently, the pellets were prepared by microfuging the complexes and washing four times with Tris-DTT buffer. The immunoprecipitated complexes were then dissolved in a sample buffer and subjected to $12.5 \%$ SDS-PAGE under reducing conditions. The gels were fixed in $10 \%$ acetic acid, treated with $1 \mathrm{M}$ salicylic acid, dried, and autoradiograms prepared. Preimmune serum was used as a control to verify the specificity of the antibody.

The specificity of the antigalectin- 9 antibody was also determined by ELISA $(36,37)$. Wells of RIA/EIA titer plates (Corning Costar Corp., Cambridge, MA) were coated with $50 \mu$ l of synthetic peptide solution $(100 \mu \mathrm{g} / \mathrm{ml})$ in $20 \mathrm{mM} \mathrm{NaHCO}, \mathrm{pH} 9.0$. The plates were allowed to dry overnight at $37^{\circ} \mathrm{C} .100 \mu$ of ice cold methanol was added to each well the next day and allowed to evaporate for $2 \mathrm{~h}$ at $37^{\circ} \mathrm{C}$. To reduce nonspecific binding of the antibody, $200 \mu \mathrm{l}$ BSA solution (5 $\mathrm{mg} / \mathrm{ml}$ ), prepared in PBS, was added, and plates left at $22^{\circ} \mathrm{C}$ for $1 \mathrm{~h}$. The wells were washed twice with PBS, and $500 \mu \mathrm{g}$ of the antibody (IgG fraction) in $50 \mu \mathrm{l}$ BSA-PBS $(100 \mu \mathrm{g} / \mathrm{ml})$ solution was added to the first well. Log dilutions of the antibody were made in successive wells and incubation was carried out with gentle shaking for $90 \mathrm{~min}$. Wells were rewashed three times with PBS containing $0.05 \%$ Tween20. Then, horseradish peroxidase-conjugated goat anti-rabbit IgG (ICN Biomedicals Inc., Costa Mesa, CA) diluted 1:1,000 in BSA-PBS solution was added and incubation was extended for $60 \mathrm{~min}$. After another three washes with Tween-20, $100 \mu \mathrm{l}$ TMB solution, containing nine parts of 3, 3', 5, 5'-tetra-methylbenzidine and one part $\mathrm{H}_{2} \mathrm{O}_{2}$ (Bio-Rad Laboratories, Hercules, CA) was added. For color development, the plates were left in the dark for $30 \mathrm{~min}$. The colorimetric reaction was stopped by the addition of $100 \mu \mathrm{l} 0.3 \mathrm{M} \mathrm{H}_{2} \mathrm{SO}_{4}$. Finally, readings at $\mathrm{OD}_{490}$ were made and plotted against log dilutions of the antibody.

For competitive inhibition ELISA assay, $250 \mu \mathrm{g}$ of recombinant galectin-9 (vide infra) was added in the first well of the peptidecoated titer plate as a competitive antigen along with $0.5 \mu \mathrm{g}$ of the antibody in $50 \mu \mathrm{l}$ of the PBS-BSA solution. Log dilutions of the antigen were made in successive wells, while the antibody concentration was kept constant. Conditions for incubation with secondary antibody and colorimetric reactions were the same as described above. Readings at $\mathrm{OD}_{490}$ were made and plotted against the log dilutions of the antigen.

The specificity of the antibody was confirmed by Western blot analyses (38). Tissues with varying degrees of galectin- 9 mRNA expression (i.e., brain, liver, and thymus) were used. Tissue extracts were prepared as described above, and they were applied to lactosyl-Sepharose columns and eluted with $0.2 \mathrm{M}$ lactose. Protein concentration in the eluates was adjusted to $50 \mu \mathrm{g} / \mathrm{ml}$, and they were subjected to $12.5 \%$ SDS-PAGE under reducing conditions. Gel proteins were electroblotted to a nitrocellulose membrane $(\mathrm{NCM})^{1}$ in a transfer buffer made up of $25 \mathrm{mM}$ Tris- $\mathrm{HCl}, 192 \mathrm{mM}$ glycine, and $20 \%$ methanol, $\mathrm{pH}$ 8.3 , at $4^{\circ} \mathrm{C}$. The NCM blot was then immersed in a blocking solution containing $4 \%$ nonfat milk and Triton X-100 TBS (0.5\% Triton X-100, $0.1 \mathrm{M}$ Tris, $0.15 \mathrm{M} \mathrm{NaCl}, \mathrm{pH} 7.5$ ), followed by successive incubations, $60 \mathrm{~min}$ each, with antigalectin-9 antibody (1:100 dilution) and goat anti-rabbit IgG conjugated with horseradish peroxidase (1:1,000 dilution) at $37^{\circ} \mathrm{C}$. The NCM blot was washed three times with Triton X-100 TBS, and then immersed in a chemiluminescent reagent (Bio-Rad Laboratories) for $1 \mathrm{~min}$. After removing the excess reagent, specific chemiluminescence was detected by making a 1-5 min contact of the NCM blot with x-ray film (Eastman Kodak Co.), followed by its development.

After confirming the specificity of the antibody, immunofluorescence microscopy was performed on tissues from 3-wk-old mice as described (35). Briefly, the mice were anesthetized and perfused with warm $\left(37^{\circ} \mathrm{C}\right)$ PBS for $1 \mathrm{~min}$ via intracardiac route to flush out the blood from various organs. $4-\mu \mathrm{m}$-thick cryostat sections of various tissues were prepared and successively incubated with anti-mouse galectin-9 and FITC goat anti-rabbit IgG antibody (ICN Biomedicals, Inc.), and examined with an ultraviolet microscope equipped with epi-illumination.

Expression and purification of recombinant proteins. Expression of recombinant protein with $\mathrm{COOH}$-terminal $c$-myc-(His) ${ }_{6}$-tag for mouse galectin-9 was carried out by using pTrcHis2 vector (Invitrogen Corp., San Diego, CA) as described in our previous publication (14). For mouse galectin-3, cDNA containing an entire coding segment was generated by PCR using mouse newborn kidney cDNA. The primers for galectin-3 were: 5'-GCACAGAGAGCATACCCAGG-3' and 5'-CTTCTGGCTTAGATCATG-3' (26). The PCR product of galectin-3 was subcloned into $\mathrm{pCR}^{\mathrm{TM}} \mathrm{II}$ vector (Invitrogen Corp.) and sequenced. The cDNA inserts of mouse galectin-3 and -9 were reamplified using the following primer sets: 5'-GGGGGGGGATCCAATGGCAGACAGCTTTTCG-3' and 5'-GGGGGGAAGCTTGATCATGGCGTGGTTAGC-3' for galectin-3; 5'-GGGGGGGGATCCGATGGCTCTCTTCAGTGCC-3' and 5'-GGGGGGAAGCTTTGTCTGCACGTGGGTCAG-3' for galectin-9, to introduce $\widehat{\mathrm{BamH}} \mathrm{I}$ and HindIII restriction sites, as underlined. These PCR products were digested with BamHI and HindIII, gel purified, and ligated into pTrcHis2A plasmid (Invitrogen Corp.) to generate galectin-3 (pTrcHis2/G3) and -9 (pTrcHis2/G9) constructs. The constructs were transfected into the $\mathrm{TOP}_{10}$ bacterial host (Invitrogen Corp.), and sequenced to ensure the proper in-frame ligation and Taq polymerase fidelity. The bacteria were allowed to grow in 1 liter of Luria broth media until an $\mathrm{OD}_{600}$ of 0.6 was achieved. Expression of fusion proteins was induced with addition of $1 \mathrm{mM}$ IPTG (isopropyl- $\beta-\mathrm{D}(-)$ -

1. Abbreviations used in this paper: NCM, nitrocellulose membrane; TUNEL, terminal deoxytransferase-mediated dUTP nick end labeling. 
thiogalactopyranoside), and further cultured for $5 \mathrm{~h}$. To isolate recombinant proteins, bacterial pellets were prepared and the cells were suspended in $100 \mathrm{ml}$ of either MEPBS buffer (PBS with $4 \mathrm{mM}$ $\beta$-mercaptoethanol, $2 \mathrm{mM}$ EDTA) $(10,13)$ or Tris-DTT buffer $(20$ $\mathrm{mM}$ Tris, $\mathrm{pH} 7.4,5 \mathrm{mM}$ EDTA, $150 \mathrm{mM}$ sodium chloride, $1 \mathrm{mM}$ DTT) (28) containing $1.25 \%$ Triton X-100, $10 \mathrm{mM}$ benzamidine, 10 $\mathrm{mM} \epsilon$-amino- $n$-caproic acid, and $2 \mathrm{mM}$ phenylmethanesulfonyl fluoride. The cells were lysed by sonication and the lysate was centrifuged at $20,000 \mathrm{~g}$ at $4^{\circ} \mathrm{C}$ for $30 \mathrm{~min}$. The supernatants were applied to a $10-\mathrm{ml}$ lactosyl-Sepharose column, unbound proteins were washed and fusion proteins were eluted either with MEPBS buffer or Tris-DTT buffer containing $200 \mathrm{mM}$ lactose. 1-ml fractions were collected and the protein concentration was determined by the Bradford method, using a BIO-RAD protein assay kit (Bio-Rad Laboratories). The purified recombinant proteins were suspended in a sample buffer $(4 \%$ SDS, $150 \mathrm{mM}$ Tris- $\mathrm{HCl}$, pH 6.8, 20\% glycerol, 0.1\% bromophenol blue, $1 \% \beta$-mercaptoethanol), resolved by $12.5 \%$ SDS-PAGE, and visualized after staining with Coomassie blue.

Mouse thymocyte and hepatocyte culture and apoptosis assay. For isolation of thymocytes, thymuses from 3-4-wk old CD1 mice were harvested, and single cell suspensions were prepared by passage through a steel mesh (\#300; Bellco Glass, Inc., Vineland, NJ). The cell suspension was subjected to Ficoll-Paque (Pharmacia LKB Biotechnology) gradient centrifugation at $400 \mathrm{~g}$ for $30 \mathrm{~min}$ to enrich viable thymocytes, which were then used for the apoptosis assay.

The isolation of hepatocytes was carried out as previously described (39). Briefly, liver was perfused in situ via abdominal aorta with calcium-free buffer $(150 \mathrm{mM} \mathrm{NaCl}, 6.7 \mathrm{mM} \mathrm{KCl}, 10 \mathrm{mM}$ Hepes, and 2 mM EDTA, $\mathrm{pH}$ 7.4) for $1 \mathrm{~min}$, followed by perfusion with collagenase buffer $(67 \mathrm{mM} \mathrm{NaCl}, 6.7 \mathrm{mM} \mathrm{KCl}, 4.7 \mathrm{mM} \mathrm{CaCl}, 100 \mathrm{mM}$ Hepes, $260 \mathrm{U} / \mathrm{ml}$ collagenase [Worthington Biochemical Corp., Freehold, NJ], $\mathrm{pH} \mathrm{7.2)} \mathrm{for} 30 \mathrm{~min}$ at $37^{\circ} \mathrm{C}$. The liver was isolated and gently teased with a pair of forceps in a petri dish while gentle shaking on an orbital shaker dispersed the hepatocytes. A single cell suspension of the hepatocytes was prepared by passage through a 110size steel mesh (Bellco Glass, Inc.), which retained the undigested liver fragments. The cell suspension was washed with DMEM containing $10 \%$ fetal bovine serum, and cultured in collagen-coated $35-\mathrm{mm}$ petri dishes (Corning Costar Corp.) at $37^{\circ} \mathrm{C}$. After a 15 -h incubation, the unattached cells were removed by washing with DMEM, and the viable attached cells, which excluded trypan blue, were used for the apoptotic assay.

Chemical agents used as stock solutions in the apoptosis assay included the following: $2 \mathrm{mM}$ dexamethasone in ethanol, $10 \mathrm{mM}$ camptothecin in DMSO, and purified recombinant galectin-3 and -9 were prepared by dialyzing four times against $1,000 \mathrm{vol} \mathrm{RPMI} 1640+3 \mathrm{mM}$ DTT at $4^{\circ} \mathrm{C}$, and the reagents were stored at $-70^{\circ} \mathrm{C}$ until further use. Thymocytes $\left(5 \times 10^{6} / \mathrm{ml}\right)$ were cultured for $0-6 \mathrm{~h}$ in RPMI $1640 \mathrm{me}-$ dium (Sigma Chemical Co.), supplemented with $10 \%$ fetal calf serum, $100 \mathrm{U} / \mathrm{ml}$ penicillin, $100 \mathrm{mg} / \mathrm{ml}$ streptomycin, and $3 \mathrm{mM}$ DTT. Dexamethasone $(1 \mu \mathrm{M})$, camptothecin $(10 \mu \mathrm{M})$, galectin-3 $(20 \mu \mathrm{M})$, and galectin-9 $(0.1-20 \mu \mathrm{M})$ were individually added into the culture media. To competitively inhibit the binding of galectin-9, lactose (10-200 $\mathrm{mM}$ ) was added to the culture media, and sucrose was used as a control. The concentrations of lactose and sucrose used were derived from the competitive inhibition studies on galectin- 1 and $-3(22,32)$. Thymocytes were harvested after $0,2,4$, and $6 \mathrm{~h}$ of exposure to various agents, and subjected to terminal deoxytransferase-mediated dUTP nick end labeling (TUNEL) reaction $(40,41)$, and washed two times with $\mathrm{PBS} / 1 \% \mathrm{BSA}$ at $4{ }^{\circ} \mathrm{C}$. After adjusting the cell concentration to $1-2 \times 10^{6} / 100 \mu$ l, they were fixed in PBS-buffered $2 \%$ paraformaldehyde. The cells were then washed with PBS, permeabilized with $0.1 \%$ Triton $\mathrm{X}-100$ in $0.1 \%$ sodium citrate for $2 \mathrm{~min}$ on ice, and rewashed. The TUNEL reaction was carried out by incubating the cells in a moist chamber for $1 \mathrm{~h}$ at $37^{\circ} \mathrm{C}$ with $50 \mu \mathrm{l}$ TUNEL reaction mixture, the latter included FITC-dUTP and terminal deoxytransferase (In Situ Cell Death Detection Kit; Boehringer Mannheim Biochemicals, Indianapolis, IN). Fluorescence and light micrographs were prepared. Approximately 500 cells from each sample were examined in randomly selected fields, and the percentage of cells undergoing apoptosis was determined. The experiments with TUNEL reactions were repeated twice, and determinations were made in triplicates. Similarly, the apoptosis assay was performed on the isolated hepatocytes $\left(2 \times 10^{5} / \mathrm{ml}\right)$ with varying concentrations $(0.1-20$ $\mu \mathrm{M})$ of galectin-9, except that DMEM was used instead of RPMI 1640.

Simultaneous detection of apoptotic cells and thymocyte-bound recombinant galectin-9 was performed on galectin-9-treated $(2.5 \mu \mathrm{M})$ cells in the presence and absence of $200 \mathrm{mM}$ lactose as follows: galectin-9-treated thymocytes were washed with PBS containing $1 \mathrm{mM}$ DTT, incubated with 1:100 diluted antigalectin-9 antibody for 30 min at $4^{\circ} \mathrm{C}$ and after another wash the cells were reincubated with rhodamine-conjugated anti-rabbit IgG antibody (ICN Biochemicals Inc.) for $30 \mathrm{~min}$ at $4^{\circ} \mathrm{C}$; subsequently, they were subjected to TUNEL reaction. In addition, control and galectin-9-treated thymocytes were harvested after $6 \mathrm{~h}$, immersed in Karnovsky's glutaraldehydeparaformaldehyde fixative, and processed for electron microscopy.

\section{Results}

Gene expression of galectin-9 in various embryonic and adult mouse tissues. By Northern blot analyses, a single $\sim 2-\mathrm{kb}$ transcript was observed that was highly expressed in adult thymus, small intestine, and liver, and to a lesser extent in lung, kidney, spleen, cardiac, and skeletal muscle (Fig. 1). In contrast, the expression in the brain was barely detectable. The
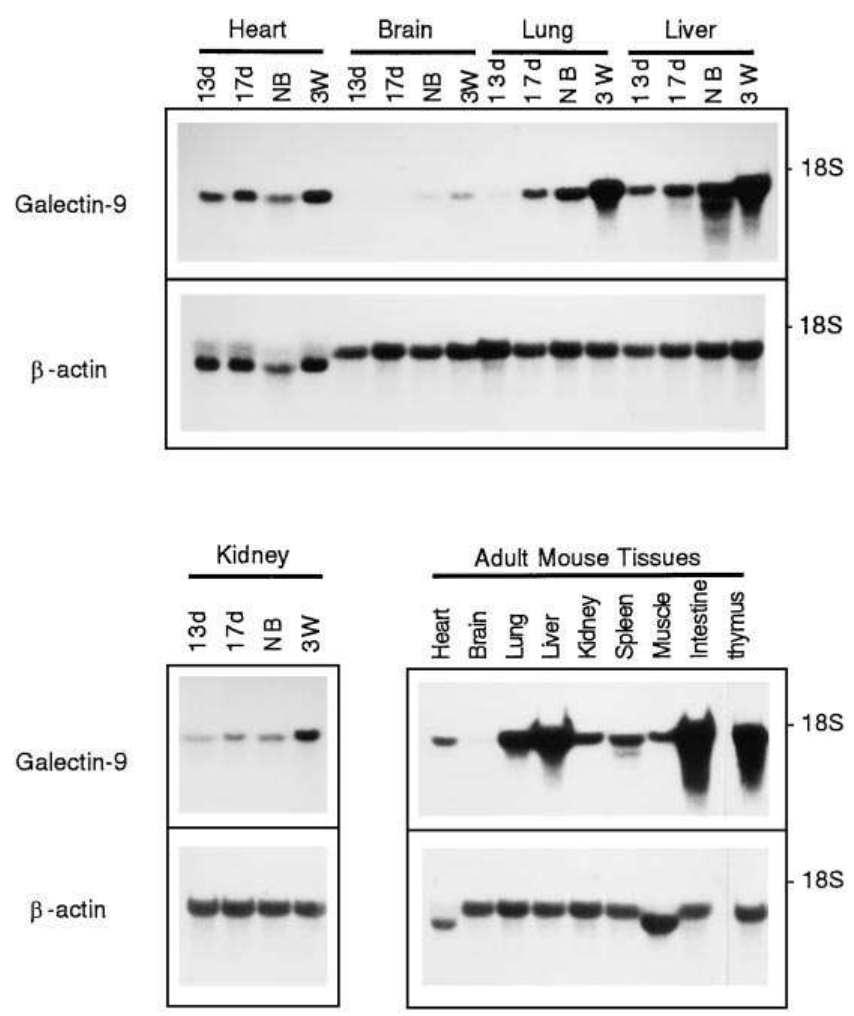

Figure 1. Northern blot analyses of galectin-9. Total RNA, isolated from embryonic and adult tissues, were blotted onto a nylon membrane and hybridized with $\left[{ }^{32} \mathrm{P}\right] \mathrm{dCTP}$-labeled galectin- 9 and $\beta$-actin cDNA. A single transcript of $\sim 2 \mathrm{~kb}$ is observed and the expression levels in the adult tissue are as follows: small intestine, thymus, and liver $>$ lung, kidney, cardiac, and skeletal muscle $>$ brain. During embryonic development, increasing mRNA expression is observed in heart, brain, lung, liver, and kidney. 


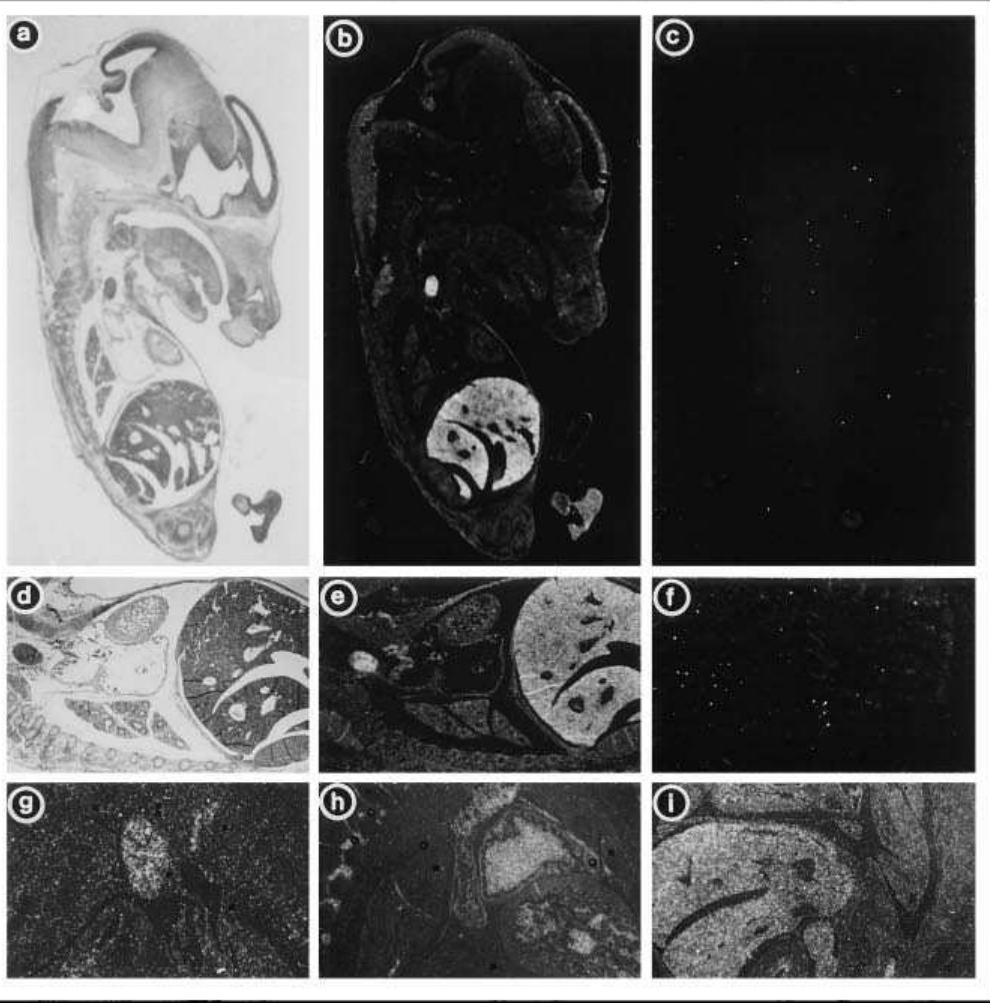

13-day Mouse Embryonic Tissues
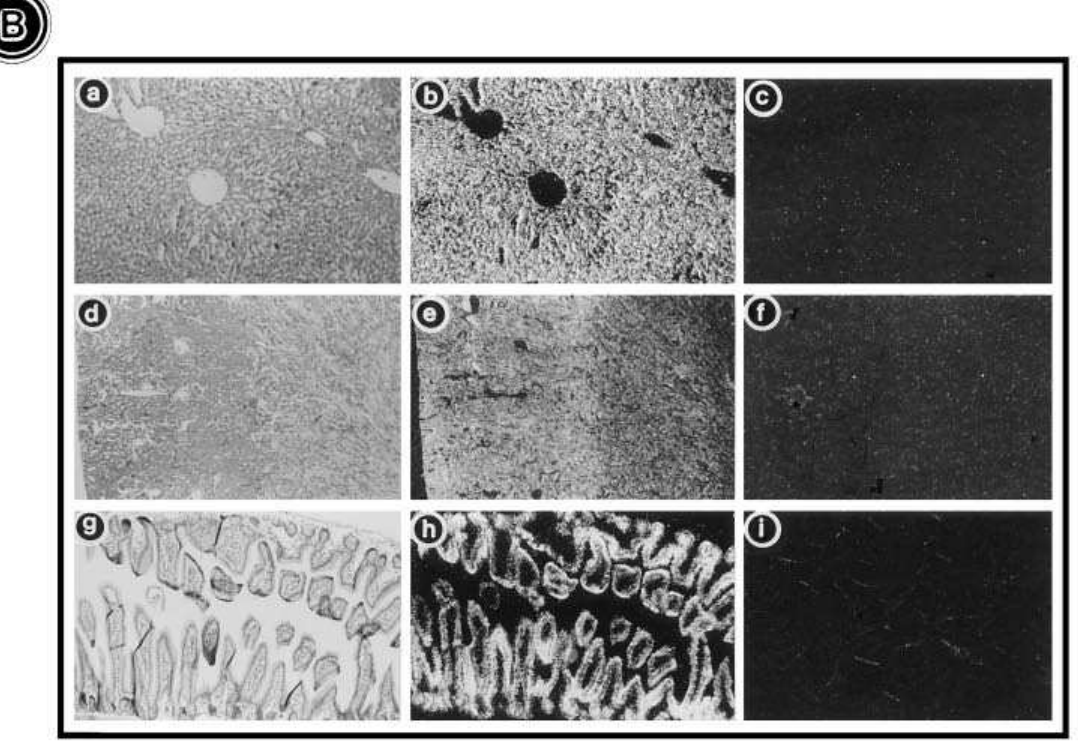

Adult Mouse Tissues
Figure 2. In situ galectin-9 mRNA localization in 13-d mouse whole embryo, adult liver, kidney, and small intestine. $(A)\left[{ }^{33} \mathrm{P}\right] \mathrm{dUTP}-$ labeled antisense and sense riboprobes of galectin-9 were hybridized with 13-d mouse whole embryo.

Bright field ( $a$ and $d$ ), and dark field photomicrographs of tissues hybridized with antisense $(b, e, g-i)$, and sense probe ( $c$ and $f$ ) are shown. Hybridization signals are noted on thymus $(b, e$, and $g)$ and liver $(b, e$, and $i)$. A few erythrocytes, trapped in the cardiac cavities, also show galectin-9 mRNA signal $(h)$. (B) Sections of adult liver $(a-c)$, kidney $(d-f)$, and small intestine $(g-i)$ are hybridized with $\left.{ }^{33} \mathrm{P}\right] \mathrm{dUTP}$-labeled antisense and sense galectin-9 riboprobes. Bright field ( $a, d$, and $g$ ) and dark field photomicrographs of tissues hybridized with antisense $(b, e$, and $h$ ) and sense ( $c, f$, and $i$ ) probes are shown. Liver parenchymal and intestinal epithelial cells exhibit galectin-9 mRNA hybridization signal $(b$ and $h)$. In the adult kidney $(e)$, the signal is seen on the cortex, where most of the glomeruli and proximal and distal tubules are located. The hybridization signal is markedly less in the medulla, where most of the collecting tubules are present. transcript was also seen in various fetal tissues (i.e., heart, brain, lung, liver, and kidney) and its expression increased with successive stages of embryonic development extending into the postnatal period; i.e., 13- and 17-d embryos to newborn and 3-wk-old mice (Fig. 1). The $\beta$-actin expression remained constant during the various stages of gestation and in the postnatal period.
To further assess the galectin-9 mRNA expression in embryonic tissues, sections of whole embryo (13-d gestation) were prepared, and in situ hybridization was performed with sense and antisense riboprobes. Abundant mRNA expression was observed in the thymus and liver (Fig. $2 A, b, e, g$, and $i$ ). The mRNA expression was seen in few fetal erythrocytes trapped in the intracardiac space (Fig. $2 A, h$ ). In other embry- 


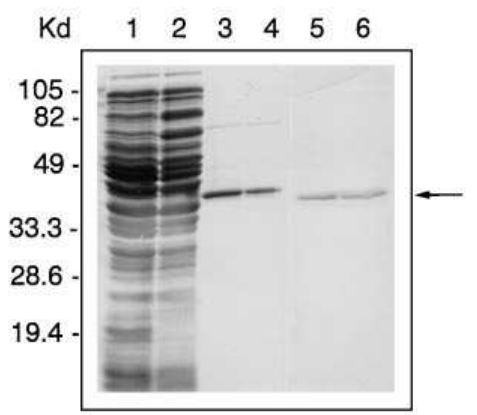

(B)

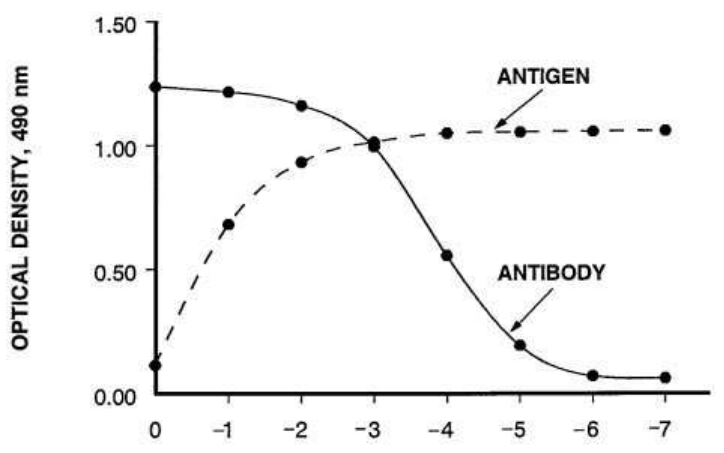

LOG DILUTIONS OF ANTIBODY OR ANTIGEN

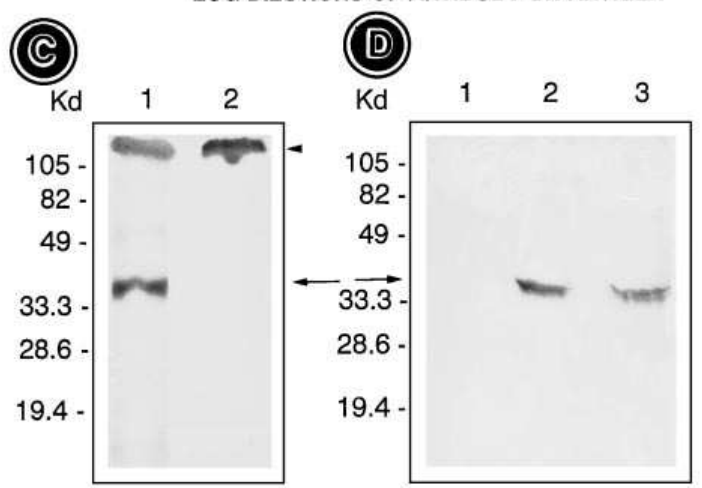

Figure 3. (A) SDS-PAGE analysis of $c$-myc-(His) $)_{6}$-tagged recombinant galectin-9 and -3. A pTrcHis2A plasmid vector and Top ${ }_{10}$ E. coli were used for generation of fusion proteins, the latter were purified by lactosyl-Sepharose chromatography in the presence of either $\beta$-mercaptoethanol (lanes 1,3, and 5) or DTT (lanes 2, 4, and 6). Total bacterial lysates were loaded in lanes 1 and 2 , purified galectin- 9 in lanes 3 and 4 , and galectin- 3 in lanes 5 and 6 . The galectin- 9 is identified by a protein band of $\sim 39 \mathrm{kD}$ (lanes 3 and 4 ), which includes a 2.5 -kD $c$-myc-(His) ${ }_{6}$ tag. The galectin- 3 has a band $\sim 36 \mathrm{kD}$ (lanes 5 and 6$)$. (B) ELISA and competitive inhibition ELISA profiles of galectin-9 antibody and recombinant galectin- 9 . A decrease in $\mathrm{OD}_{490}$ readings is observed with increasing log dilutions of antigalectin-9 antibody (solid line), while an increase in $\mathrm{OD}_{490}$ readings is observed with increasing $\log$ dilutions of the competitive antigen; i.e., recombinant galectin-9 (dotted line). (C) SDS-PAGE autoradiogram of endogenous de novo synthesized and immunoprecipitated galectin- 9 . Newborn mice were radiolabeled with $\left[{ }^{35}\right.$ S]methionine and thymuses were harvested, homogenized, and subjected to lactosyl-Sepharose chromatography followed by immunoprecipitation with antigalectin- 9 antibody. The de novo synthesized native galectin-9 is visualized as a band of $M_{\mathrm{r}} \sim 36 \mathrm{kD}$ (lane 1 ) as indicated by the arrow. The arrow head indicates the point of application. No band is seen when preimmune serum was used for immunoprecipitation (lane 2). (D) Western onic tissues (i.e., lung, heart, kidney, and small intestine), the expression was low but detectable when compared with the signal over the control tissues hybridized with sense riboprobe (Fig. $2 A, e$ vs. $f$ ). In adult tissues, galectin-9 mRNA expression was seen in the hepatocytes (Fig. $2 B, a$ and $b$ ), epithelial cells of small intestine (Fig. $2 B, g$ and $h$ ), and glomerular and tubular cells of the renal cortex (Fig. $2 B, d$ and $e$ ). The expression of galectin-9 in the renal medullary tubules was low. Galectin-9 expression was also observed in cardiac and skeletal muscle cells (not shown).

Specificity of the antigalectin-9 antibody and protein expression in various tissues. Specificity of the antibody was ascertained by four different methods, ELISA, competitive inhibition ELISA, immunoprecipitation, and Western blot analyses. In the ELISA assay, a fixed amount of antigen (i.e., synthetic peptide) and serial log dilutions of the antibody were used. With increasing dilutions of the antibody, a proportionate decrease in $\mathrm{OD}_{490}$ readings was observed (Fig. $3 \mathrm{~B}$, solid line). In the competitive inhibition ELISA assay, a fixed amount of diluted antibody (1:000) along with serial log dilutions of the competitive antigen (i.e., recombinant galectin-9) were added into the wells of the titer plate coated with the synthetic peptide. With increasing dilutions of the competitive antigen, a proportionate increase in $\mathrm{OD}_{490}$ readings was observed (Fig. $3 \mathrm{~B}$, dotted line), documenting the specificity of antigalectin- 9 antibody.

SDS-PAGE analysis of $\left[{ }^{35}\right.$ S $]$ methionine-labeled thymic proteins, immunoprecipitated with antigalectin antibody, revealed a single $\sim 36-\mathrm{kD}$ band (Fig. $3 C$, lane 1 ). No band was seen when immunoprecipitation was carried out with preimmune serum (Fig. $3 C$, lane 2). Western blot analyses revealed a single $\sim 36-\mathrm{kD}$ band in the liver (Fig. $3 D$, lane 2 ) and thymus (Fig. $3 D$, lane 3 ) extracts. No band of chemiluminescence could be seen in the brain extract (Fig. $3 \mathrm{D}$, lane 1 ), suggesting undetectable or extremely low expression of galectin-9 in the neuronal tissues, similar to that observed by Northern blot analyses. The results of these four methods clearly establish the specificity of antigalectin- 9 antibody.

By immunofluorescence microscopy, galectin-9 was also found widely distributed in various tissues. Besides its intracellular localization, it was highly expressed on the plasmalemma of certain epithelial cells, suggesting that like other galectins it was probably externalized by some nonclassical mechanism as proposed by Barondes et al. (3) and Cooper and Barondes (42). In contrast with the diffuse mRNA expression of galectin-9 in the adult liver, the immunoreactivity of the antibody was confined to the cell surfaces of the hepatocytes, especially on the sinusoidal front (Fig. 4, $a-c$ ). In the renal cortex, a diffuse staining of the tubular cells was observed; however, the medullary tubules exhibited low immunoreactivity (Fig. $4 d$ ).

blot (immunoblot) analyses of protein extracts of brain, liver, and thymus. The tissues were harvested, homogenized, and subjected to lactosyl-Sepharose chromatography followed by SDS-PAGE. The proteins were electroblotted onto a nitrocellulose membrane. The blot was successively immersed in solutions containing antigalectin- 9 antibody and horseradish peroxidase anti-rabbit IgG. The blotted proteins were then detected by chemiluminescence method. A band of $M_{\mathrm{r}} \sim 36 \mathrm{kD}$ is seen in the liver and thymic extracts (lanes 2 and 3). The band is undetectable in the brain extract (lane 1), suggesting an extremely low expression of galectin-9 in the neuronal tissue. 


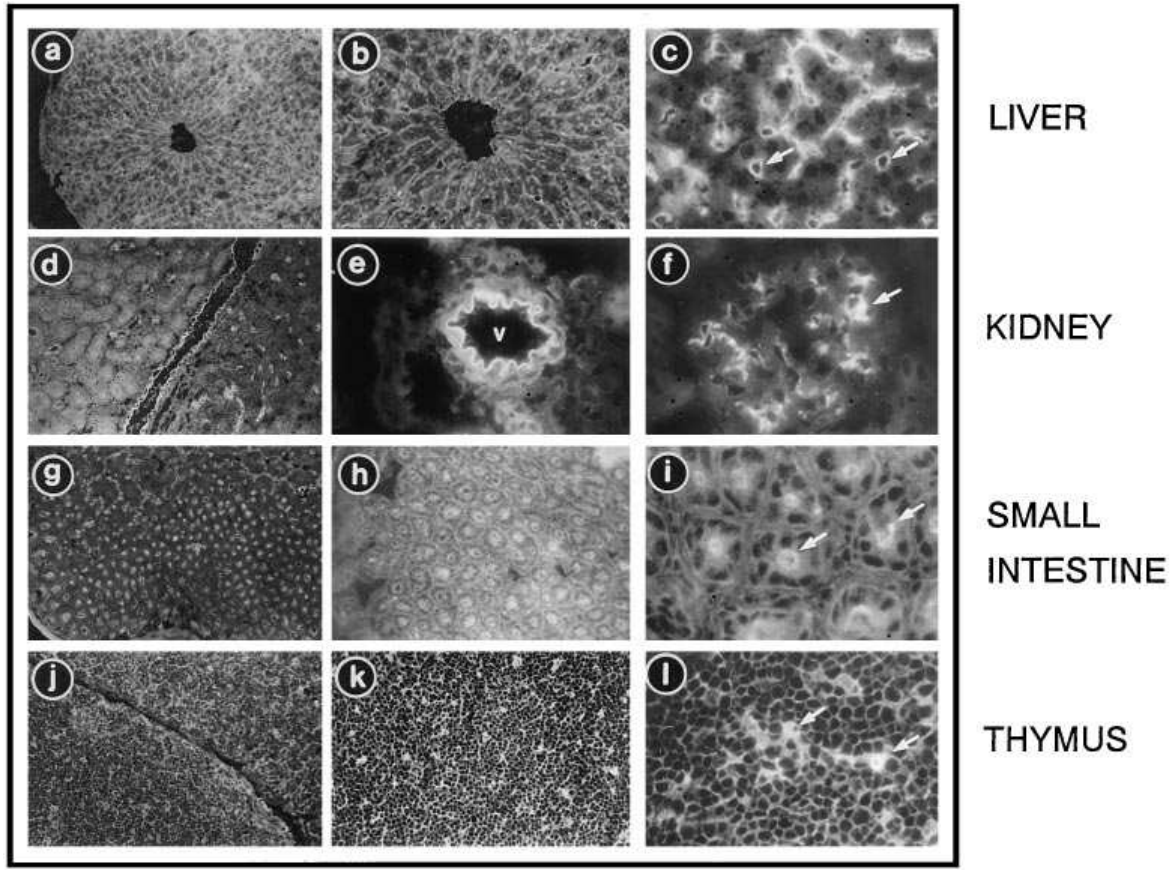

Figure 4. Low and high magnification immunofluorescence micrographs of various mouse tissues stained with specific polyclonal anti-mouse galectin- 9 antibody, directed against the link peptide. In liver, galectin-9 is localized in the hepatocyte ( $a$ and $b$ ), especially on the sinusoidal front (c, arrows). In kidney, galectin-9 is seen on the cortical tubules and intertubular capillaries, especially of the medulla $(d)$. The galectin-9 reactivity is also seen in the blood vessels $(e, v)$ and glomerular mesangium $(f$, arrow $)$. In small intestine, epithelial cells of the crypts are intensely stained with antigalectin- 9 antibody $(g-i)$. The immunoreactivity is readily seen in the luminal surface of the cells lining the crypts (i, arrows). In thymus, thymic epithelial/ stromal cells display immunoreactivity in the cortex and medulla ( $j$ and $k$ ). The reactivity of galectin-9 in the stromal cells and their dendritic processes is readily seen in $l$ (arrows).

The arterioles and intertubular capillaries of both the medulla and cortex exhibited a moderate degree of galectin- 9 expression (Fig. $4 e$ ), and its expression was seen in the glomerular mesangium as well (Fig. $4 f$ ). In small intestine, the epithelial cells exhibited intense immunoreactivity (Fig. 4, $g-i$ ). The expression was relatively high in the apical regions of the cells lining the crypts, as seen in the high magnification micrograph of the intestine (Fig. $4 i$ ). These findings are in line with the in situ data that indicate a relatively high mRNA expression of galectin-9 in the epithelial cells lining the crypts of the small intestine (Fig. $2 B, h$ ). In the thymus, galectin-9 was expressed in the stromal/epithelial cells (Fig. $4, j-l$ ). The immunoreactivity was seen as a reticulum network outlining the dendritic processes of the stromal/epithelial cells of the thymus (Fig. $4 l$ ). Skeletal and cardiac myocytes also expressed galectin-9 (not shown). Collectively, the expression profile data indicate that galectin-9 is widely distributed in various cell types of mammalian tissues.

Generation of recombinant galectin-9 and apoptosis assays. Since galectin-9 was highly expressed in the thymus, one may envision the role of galectin-9 in thymocyte-stromal cell interactions during embryonic life. With this possibility in mind, recombinant galectin-9 (r-galectin-9) was prepared to study the developmental processes relevant to the biology of the thymus (e.g., apoptotic clonal deletion of the thymocytes) since most thymocytes gradually undergo apoptosis. The latter could be mediated via interactions between thymocytes and thymic stromal cells.

In the Escherichia coli host, IPTG-inducible expression of r-galectin-9 and -3 was observed within $5 \mathrm{~h}$. The SDS-PAGE analyses of the transfected and nontransfected $E$. coli lysates, prepared in the presence of $\beta$-mercaptoethanol or DTT, revealed multiple bands (Fig. $3 A$, lanes 1 and 2). The lactosylSepharose column-purified galectin-9 and -3 revealed $\sim 39$ and $36-\mathrm{kD}$-size bands, respectively, by SDS-PAGE analyses, and their molecular weights included $2.5-\mathrm{kD} c$-myc-(His) ${ }_{6}$-tag. These data suggested that the recombinant proteins have comparable molecular size and they retain lactose binding activity, and thus are suitable for functional studies.

For the apoptosis assay, mouse thymocytes were isolated by Ficoll-Paque gradient, and incubated with r-galectin- 9 and known thymocyte apoptosis inducers (i.e., dexamethasone and camptothecin), which are endowed with differential potencies and served as positive controls (40). Additional controls included incubation of thymocytes either with galectin-3 or $-9+$ 10-200 mM lactose. To assess apoptosis, an in situ TUNEL reaction was performed. In the untreated control, $4-5 \%$ of the thymocytes exhibited apoptosis at $0-6 \mathrm{~h}$ in culture (Fig. 5, A, $a$ and $B, a$ and $b$ ). At $6 \mathrm{~h}, 40.7 \pm 7.2 \%$ of thymocytes exhibited apoptosis in the presence of $1 \mu \mathrm{M}$ dexamethasone (Fig. 5, $A, a$ and $B, c$ and $d)$. Camptothecin $(10 \mu \mathrm{M})$ had a marginal apoptotic effect (10.7 $\pm 1.8 \%$ ) (Fig. 5, $A, a$ and $B, e$ and $f$ ).

Treatment of thymocytes with various concentrations of r-galectin-9-induced dose- and time-dependent apoptosis (Fig. $5 A, a$ and $b$ ). At $2.5 \mu \mathrm{M}$, a maximal effect was observed, and $26.6 \pm 2.7 \%$ of thymocytes exhibited apoptosis. A mild degree of aggregation of the thymocytes was also observed at this concentration (Fig. $5 B, g$ and $h$ ). The aggregation or agglutination of thymocytes was accentuated at $10-$ and $20-\mu \mathrm{M}$ concentration of galectin-9 in the culture medium (Fig. $5 B, i-l$ ). At 20$\mu \mathrm{M}$ concentration of r-galectin-9, extensive agglutination of the thymocytes was observed (Fig. $5 B, k$ and $l$ ). Galectin-9induced apoptosis was competitively inhibited by lactose in a dose-dependent (10-200 mM) manner, while sucrose did not exhibit any significant effect (Fig. $5 A, a$ and $c$ ). Lastly, inclusion of $20 \mu \mathrm{M}$ of r-galectin-3 into the culture did not increase apoptosis from control basal levels (Fig. $5 A, a$ ).

By electron microscopy, $\sim 60 \%$ of the thymocytes exhibited apoptosis with the inclusion of $2.5 \mu \mathrm{M}$ r-galectin- 9 in the culture medium (Fig. $5 C, b$ vs. $a$ ), and the degree of apoptosis 
(A)
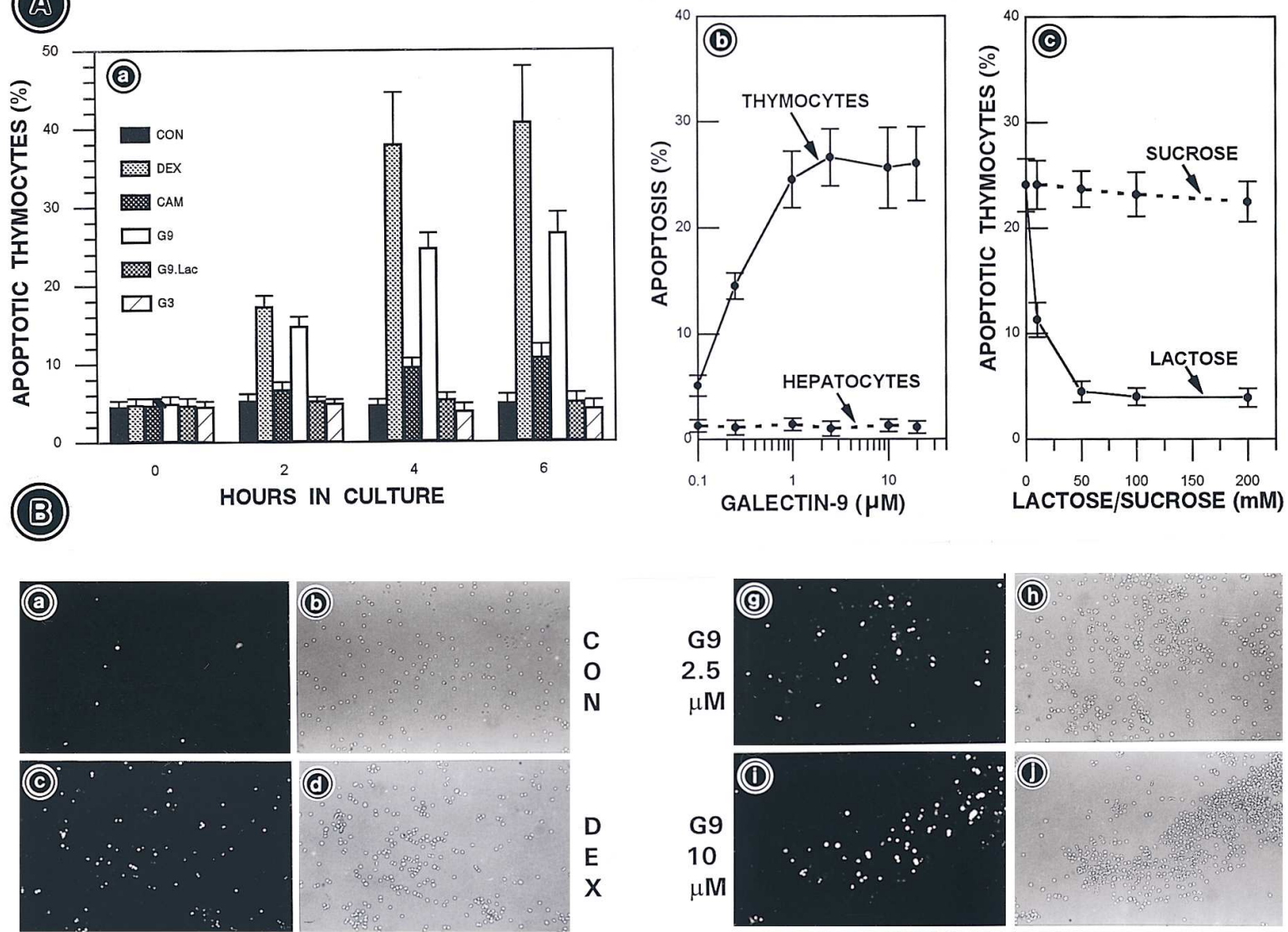

(d)
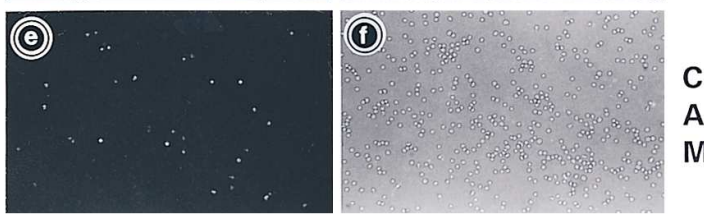

(C)
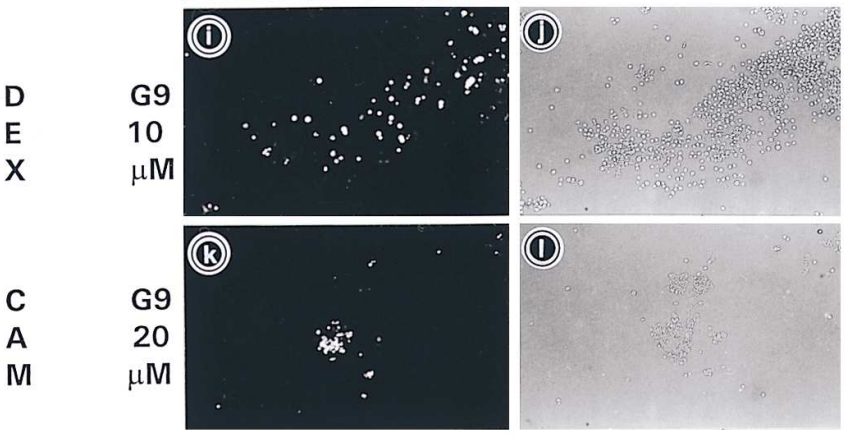

\section{(D)}

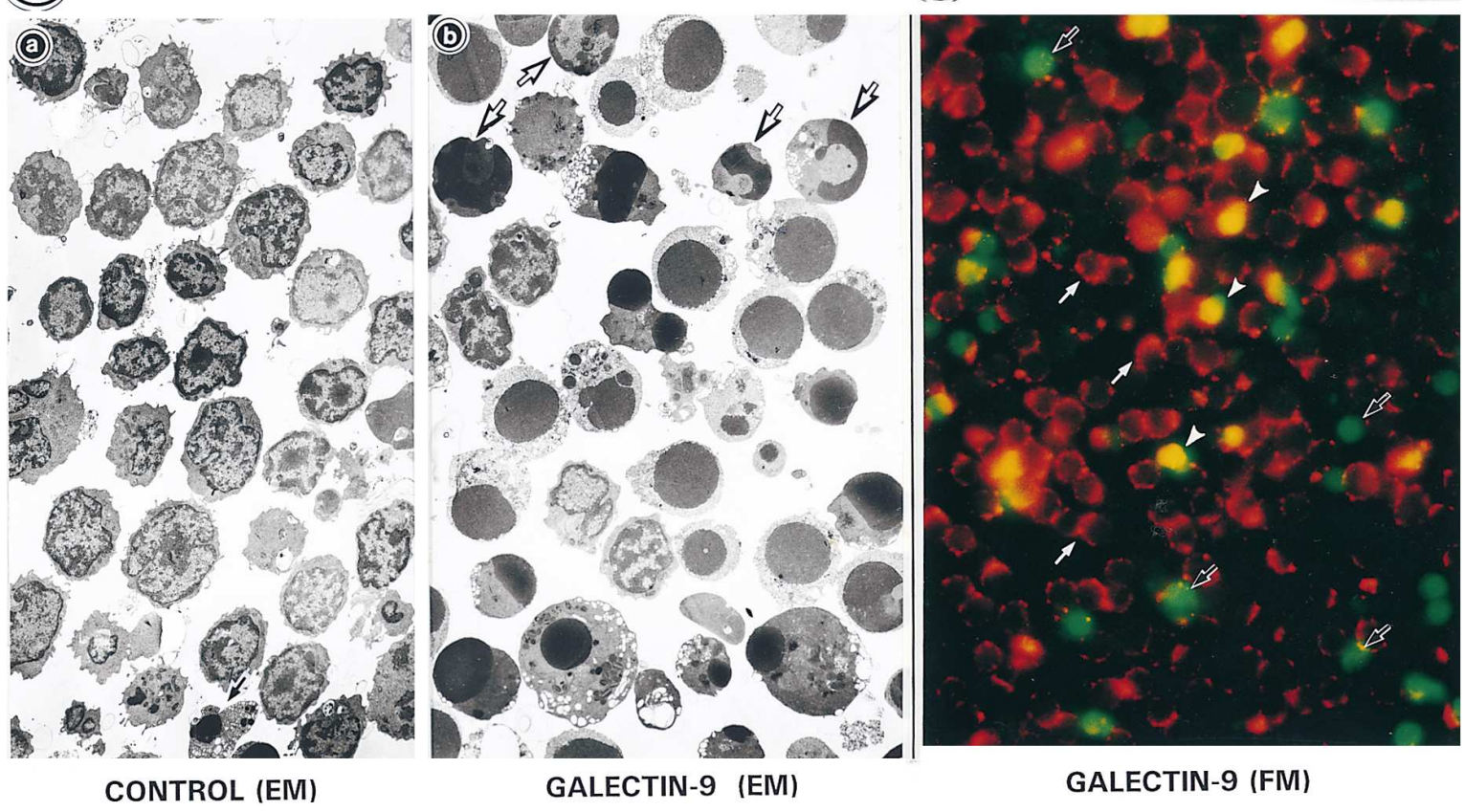


appeared to be similar to that induced by dexamethasone (not shown). Apoptotic bodies in the various stages of development were frequently observed. Most of them were made up of a single uniformly condensed chromatin mass, while other cells had two to three discrete globular fragments of the condensed chromatin (Fig. $5 C, b$ ). In addition, several nuclear crescents of peripheral compacted chromatin were observed (Fig. 5C, $b$, arrows). Also, many thymocytes in advanced stages of apoptosis exhibited quite an extensive damage to their nuclear and cytoplasmic membranes. Such a loss of membrane integrity could lead to a leakage of the TUNEL reaction product, and this may account for the relatively low number of apoptotic cells detected by this method compared with electron microscopy. In the control, an occasional apoptotic body was seen (Fig. 5 C, a, arrow).

To elucidate the binding of r-galectin- 9 to the cell surfaces, thymocytes were exposed to r-galectin- 9 for $5 \mathrm{~h}$ in the presence or absence of $0.2 \mathrm{M}$ lactose, and then successively exposed to antigalectin-9 and anti-rabbit IgG conjugated with rhodamine. Subsequently, the thymocytes were fixed with $2 \%$ paraformaldehyde, and an in situ TUNEL reaction was performed. A uniform plasmalemmal binding of r-galectin-9 with thymocytes was observed (Fig. $5 \mathrm{D}, \mathrm{red}$ ). No binding of r-galectin-9 was seen in the thymocytes incubated in the presence of $0.2 \mathrm{M}$ lactose (not included). Many thymocytes undergoing apoptosis were observed (Fig. 5 D, green). In addition, some of the thymocytes exhibiting apoptosis had plasmalemmal-bound galectin (Fig. $5 \mathrm{D}$, yellow), suggesting that the apoptosis ensued after the binding of galectin-9. Conceivably, the thymocytes exhibiting only green fluorescence may represent the later stages of apoptosis when the cell membrane integrity has already been compromised and the galectin is no longer bound to the cell. Alternatively, since the plasmalemma and the nucleus are not in the same plane of focus, both processes, binding of galectin- 9 and apoptosis, may be difficult to visualize in the same cell.

To assess whether or not the galectin-9-induced effect is restricted to thymocytes, apoptosis in hepatocytes, which exhibit a high degree of expression, was studied. No significant apoptosis was observed in the hepatocytes with the exposure of r-galectin-9, up to a concentration of $20 \mu \mathrm{M}$, for $6 \mathrm{~h}$ in culture (Fig. $5 A, b)$.

\section{Discussion}

The results of this investigation indicate that galectin-9, like galectin-1, -3 , and -8 (3), is widely distributed in various tissues with a variable degree of expression. However, literature data documenting the spatio-temporal expression of galectins during various stages of the embryonic development is rather sparse. The fact that galectin- 9 exhibits temporal expression in various tissues during different stages of the gestation suggests that it, conceivably, plays a role in the embryonic development of various organ systems. Such a vital role of galectins needs to be explored, and it is very likely that the subject matter of developmental biology of the galectins will be an exciting area of future investigations since these molecules are involved in cell-cell and cell-matrix interactions, critical processes guiding the morphogenesis of various organs, including kidney, lung, and mammary, salivary, and prostate glands.

With respect to embryonic development, the data of in situ hybridization studies on the 13-d mouse embryo revealed an exuberant expression of galectin-9 mRNA in the developing thymus and liver. The abundance of galectin- 9 mRNA in the liver and thymus persisted throughout the neonatal and postnatal periods. Such an accentuated expression in the liver and thymus was also observed by immunofluorescence, where a specific polyclonal antibody raised against the unique link peptide of the galectin-9 was used. Such an exclusively high expression of galectin-9 in the thymus during embryonic life has not been reported for any other known galectin $(3,25)$. The fact that the thymus had a persistently high galectin- 9 gene and protein expressions, especially in the thymic epithelial (stromal) cells, led us to believe that galectin- 9 may be relevant to the immunobiology of the thymocyte (e.g., thymocyte-stromal/epithelial cell juxtacrine/paracrine interactions) and thymocyte apoptosis.

Apoptosis, or programmed cell death, constitutes a series of biological events leading to a deliberate elimination of cells to maintain proper homeostasis during embryonic development (43). In particular, it plays a vital role in the clonal deletion or negative selection of selfreactive $\mathrm{T}$ cells during thymocyte development, since the vast majority of cortical thymocytes $(97 \%)$ die in the thymus and only $3 \%$ are positively selected and migrate to the peripheral circulation. During this clonal

Figure 5. Apoptosis profiles of mouse thymocytes and hepatocytes. $(A)$ Thymuses were harvested from 3-4-wk-old mice, and thymocytes were purified by Ficoll-Paque gradient and individually exposed to $1 \mu \mathrm{M}$ dexamethasone $(D E X), 10 \mu \mathrm{M}$ camptothecin $(C A M), 2.5 \mu \mathrm{M}$ galectin-9 (G9), $2.5 \mu \mathrm{M}$ galectin-9 + 0.2 M lactose (G9.Lac), and $20 \mu \mathrm{M}$ galectin-3 (G3). Apoptotic thymocytes were detected by TUNEL method using FITC dUTP. Galectin-9 induces thymocyte apoptosis in a time-dependent $(a)$, dose-dependent $(b)$, and lactose-inhibitory manner, and the effect is as follows: dexamethasone $>$ galectin-9 $>$ camptothecin $(a)$. The hepatocytes, isolated by the method of Seglen (39), do not exhibit any significant apoptosis upon exposure to galectin-9 $(b)$. The apoptosis in thymocytes is inhibitable with lactose in a dose-dependent manner $(c)$, while it is not inhibited by sucrose. (B) Fluorescence micrographs $(a, c, e, g, i$, and $k)$ and light micrographs $(b, d, f, h, j$, and $l)$ of control cells $(a$ and $b)$, and thymocytes treated for $6 \mathrm{~h}$ with dexamethasone $(c$ and $d)$, camptothecin $(e$ and $f), 2.5 \mu \mathrm{M}$ galectin-9 $(g$ and $h), 10 \mu \mathrm{M}$ galectin-9 $(i$ and $j), 20$ $\mu \mathrm{M}$ galectin-9 $(k$ and $l)$, and subjected to TUNEL procedure to detect apoptotic cells. Galectin-9-treated thymocytes exhibit apoptosis, which is comparable with that induced by dexamethasone ( $c$ and $d$ vs. $g$ and $h$ ); in addition, it induces homotypic aggregation of thymocytes in a dosedependent manner $(g-l)$. $(C)$ Electron micrographs of thymocytes exhibiting galectin-9-induced apoptosis. In untreated control $(a)$, an occasional cell (arrow) undergoing apoptosis is seen. In the galectin-9-treated group (b), numerous (50-60\%) cells exhibiting apoptosis are seen. Many cells have single dense chromatin mass, some contain two to three round dense apoptotic bodies, while the nuclei of other cells show peripheral compacted chromatin forming crescents (arrows). (D) Fluorescence micrograph of the thymocytes with plasmalemmal-bound exogenous recombinant galectin-9 stained with primary polyclonal and secondary rhodamine-conjugated antibody (red fluorescence, white arrows). The thymocytes undergoing apoptosis are detected by the TUNEL procedure where FITC dUTP was used, and they exhibit green nuclear fluorescence (black/white arrows). Some of the thymocytes exhibit concomitant plasmalemmal binding of recombinant galectin-9 and apoptosis (yellow fluorescence, arrowheads), suggesting that the apoptosis ensued after the binding of galectin-9. 
deletion, a number of adhesion molecules, including receptor and counter receptor pairs CD2 and LFA-3, and LFA-1 and intercellular adhesion molecule-1 that are expressed on the thymocytes and thymic epithelial cells, have been shown to participate in cell-cell interactions $(44,45)$. In addition to cell surface protein-protein interactions, many investigators have suggested a potential involvement of carbohydrate-protein interactions in thymocyte-thymic epithelial (stromal) cell adhesion processes $(3,22)$. In view of the above considerations, the dimeric carbohydrate domains, endowing bivalent binding properties to galectin-9, are ideally suited to accomplish adhesive interactions by bridging of the glycoconjugate molecules expressed on the different cell types. This notion is supported by our experiments in which incubation of mouse thymocytes with r-galectin-9 resulted in the homotypic aggregation of the cells in a dose-dependent manner, although at relatively high concentrations of galectin-9; i.e., 2.5-20 $\mu \mathrm{M}$. In contrast, a dose-dependent induced apoptosis could be achieved at relatively low concentrations of r-galectin-9; i.e., $0.25-2.5 \mu \mathrm{M}$. This would suggest that apoptosis was induced by cell surface binding of galectin-9 (i.e., carbohydrate-protein interaction) and not subsequent to homotypic cell aggregation. The data with regard to galectin-induced apoptosis of thymocytes is not available in the literature, but PHA-stimulated peripheral T cells in vitro have been shown to undergo apoptosis with the exposure to galectin-1. It is difficult to compare the potencies of two galectins since, in the latter, transformed lymphoblastoid cells were used (23). However, comparative analyses of the experiments with other apoptosis inducers indicate that galectin-9 is endowed with a potency almost comparable with that of dexamethasone. The mechanism(s) involved in the induction of apoptosis by these agents may be different, but, most likely, galectin-9-induced apoptosis was mediated via binding with specific galactosyl groups since the effect could be competitively inhibited with $0.2 \mathrm{M}$ lactose.

Although all members of the galectin family contain $\beta$-galactoside binding domains, they do not consistently induce apoptosis. For instance, galectin-3 does not induce apoptosis of the thymocytes (Fig. $5 A$ ). On the contrary, human T cell leukemia cell line (Jurkat E6-1), transfected with galectin-3 cDNA, has been reported to be not susceptible to Fas-antibody-mediated apoptosis (31). Interestingly, galectin-3 and $\mathrm{Bcl}-2$ share the NWGR motif, which is highly conserved in Bcl-2 family of proteins $(46,47)$. Conceivably, this motif is critical for the lactoseinhibitable intracellular heterodimerization of Bcl-2/galectin-3, and in negating Fas-antibody-mediated apoptosis (31). Homology alignment has revealed that the NWGR motif overlaps XWGXEER-conserved sequences of the galectin family, and thus the observed opposing biological effects of galectin-3 vs. galectin- 1 or -9 are rather intriguing. The motif in the overlapping segments of galectin-1 is AWGT, and that of galectin-9 are QWGP and SWGQ in the respective $\mathrm{NH}_{2}-$ and $\mathrm{COOH}-$ terminal carbohydrate binding domains. Therefore, one may speculate that the differential effects may be related to the NWGR motif, which is exclusively present in galectin-3. Certainly, further site-directed mutagenesis studies are needed to map various regions of galectin-9 that are involved in the process of apoptosis. Lastly, the biological effects may also vary with the level of expression and tissue distribution of a given galectin. Galectin-9 is constitutively and abundantly expressed in the thymic epithelial cells, whereas galectin-3 is present in low levels in the $\mathrm{T}$ cells and its expression is upregulated by $\mathrm{CREB}$ and nuclear factor- $\mathrm{\kappa B}$, and in transformed cells (31, 48, 49).

Although galectin-9 binding was mediated via $\beta$-galactosyl groups (vide supra), direct evidence for the galectin-9-induced apoptosis after its binding with the thymocytes was provided by the immunofluorescence studies. A uniform plasmalemmal binding of galectin-9, associated with numerous thymocytes undergoing concomitant apoptosis in vitro, was observed with its addition in the culture medium. As to the events related to the in vivo thymic biology of galectin- 9 , one may speculate that it binds to the glycoconjugate receptor(s) on the thymocyte surface after its secretion from thymic epithelial cells, or, alternatively, it may mediate its bridging effect while being still bound to the thymic epithelium via its putative counter receptor. The nature of such a counter receptor(s) that is involved in the galectin-9-induced apoptosis remains to be investigated. The potential candidate(s) for the counter receptor(s) may include leukosialin (CD43) or leukocyte common antigen (CD45) since both bind to other galectins (i.e., galectin-1, reference 20), and CD45 has been proposed to participate in apoptosis (50).

In conclusion, these studies indicate that galectin- 9 has a broad tissue distribution with exclusively high expression in the developing thymus where it conceivably plays an essential role in the clonal deletion of $\mathrm{T}$ cells via thymic epithelial cellthymocyte interactions leading to apoptosis.

\section{Acknowledgments}

Supported by National Institutes of Health grant DK-28492.

\section{References}

1. Varki, A. 1993. Biological roles of oligosaccharides: all of the theories are correct. Glycobiology. 3:97-130.

2. Barondes, S.H., V. Castronovo, D.N.W. Cooper, R.D. Cummings, K. Dickamer, T. Feizi, M.A. Gitt, J. Hirabayashi, C. Hughes, K. Kasai, et al. 1994. Galectins: a family of animal $\beta$-galactoside binding lectins. Cell. 76:597-598.

3. Barondes, S.H., D.N.W. Cooper, M.A. Gitt, and H. Leffler. 1994. Galectins. Structure and function of a large family of animal lectins. J. Biol. Chem. 269:20807-20810.

4. Hirabayashi, J., and K. Kasai. 1993. The family of metazoan metal-independent $\beta$-galactoside-binding lectins: structure, function, and molecular evolution. Glycobiology. 3:297-304.

5. Pfeifer, K., M. Haasemann, V. Gamulin, H. Bretting, F. Fahrenholz, and W.E. Müller. 1993. S-type lectins occur also in invertebrates: high conservation of the carbohydrate recognition domain in the lectin genes from the marine sponge Geodia cydonium. Glycobiology. 3:179-184.

6. Couraud, P.O., D. Casentini-Borocz, T.S. Bringman, J. Griffith, M. McGrogan, and G.E. Nedwin. 1989. Molecular cloning, characterization and expression of a human 14-kDa lectin. J. Biol. Chem. 264:1310-1316.

7. Gitt, M.A., S.M. Massa, H. Leffler, and S.H. Barondes. 1992. Isolation and expression of a gene encoding L-14-II, a new human soluble lactose-binding lectin. J. Biol. Chem. 267:10601-10606.

8. Robertson, M.W., K. Albrandt, D. Keller, and F.T. Liu. 1990. Human IgE-binding protein: a soluble lectin exhibiting a highly conserved interspecies sequence and differential recognition of IgE glycoforms. Biochemistry. 29: 8093-8100.

9. Oda, Y., J. Herrmann, M.A. Gitt, C.W. Turck, A.L. Burlingame, S.H. Barondes, and H. Leffler. 1993. Soluble lactose-binding lectin from rat intestine with two different carbohydrate-binding domains in the same peptide chain. $J$. Biol. Chem. 268:5929-5939.

10. Gitt, M.A., M.F. Wiser, H. Leffler, J. Herrmann, Y.R. Xia, S.M. Massa, D.N.W. Cooper, A.J. Lusis, and S.H. Barondes. 1995. Sequence and mapping of galectin-5, a $\beta$-galactoside-binding lectin, found in rat erythrocytes. J. Biol. Chem. 270:5032-5038.

11. Madsen, P., H.H. Rasmussen, T. Flint, P. Gromov, T.A. Kruse, B. Honore, H. Vorum, and J.E. Celis. 1995. Cloning, expression, and chromosome mapping of human galectin-7. J. Biol. Chem. 270:5823-5829.

12. Magnaldo, T., F. Bernerd, and M. Darmon. 1995. Galectin-7: a human 14-kDa S-lectin, specifically expressed in keratinocytes and sensitive to retinoic acid. Dev. Biol. 168:259-271.

13. Hadari, Y.R., K. Paz, R. Dekel, T. Mestrovic, D. Accili, and Y. Zick. 
1995. Galectin-8. A new rat lectin, related to galectin-4. J. Biol. Chem. 270: 3447-3453.

14. Wada, J., and Y.S. Kanwar. 1997. Identification and characterization of galectin-9, a novel $\beta$-galactoside binding mammalian lectin. J. Biol. Chem. In press.

15. Leonidas, D.D., B.L. Elbert, Z. Zhou, H. Leffler, S.J. Ackerman, and K.R. Acharya. 1995. Crystal structure of human Charcot-Leyden crystal protein, an eosinophil lysophospholipase, identifies it as a new member of the carbohydrate-binding family of galectins. Structure (Lond.). 3:1379-1393.

16. Dyer, K.D., and H.F. Rosenberg. 1996. Eosinophil Charcot-Leyden crystal protein binds to $\beta$-galactoside sugars. Life Sci. 58:2073-2082.

17. Leffler, H. 1997. Introduction to galectins. Trends Glycosci. Glycotech. In press.

18. Cooper, D.N.W., S.M. Massa, and S.H. Barondes. 1991. Endogenous muscle lectin inhibits myoblast adhesion to laminin. J. Cell Biol. 115:1437-1448.

19. Gu, M., W. Wang, W.K. Song, D.N.W. Cooper, and S.J. Kaufman. 1994. Selective modulation of the interaction of $\alpha 7 \beta 1$ integrin with fibronectin and laminin by L-14 lectin during skeletal muscle differentiation. J. Cell Sci. 107: $175-181$

20. Wells, V., and L. Mallucci. 1991. Identification of an autocrine negative growth factor: mouse $\beta$-galactoside-binding protein is a cytostatic factor and cell growth regulator. Cell. 64:91-97.

21. Clyman, R.I., J. Tannenbaum, Y.Q. Chen, D.N.W. Cooper, P.D. Yurchenco, R.H. Kramer, and N.S. Waleh. 1994. Ductus arteriosus smooth muscle cell migration on collagen: dependence on laminin and its receptors. J. Cell Sci. 107:1007-1018.

22. Baum, L.G., M. Pang, N.L. Perillo, T. Wu, A. Delegeane, C.H. Uittenbogaart, M. Fukuda, and J.J. Seilhamer. 1995. Human thymic epithelial cells express an endogenous lectin, galectin-1 which binds to core 2 O-glycans on thymocytes and T lymphoblastoid cells. J. Exp. Med. 181:877-887.

23. Perillo, N.L., K.E. Pace, J.J. Seilhamer, and L.G. Baum. 1996. Apoptosis of T cells mediated by galectin-1. Nature (Lond.). 378:736-739.

24. van den Brûle, F.A., C. Buicu., M. Baldet, M.E. Sobel, D.N.W. Cooper, P. Marschal, and V. Castronovo. 1995. Galectin-1 modulates human melanoma cell adhesion to laminin. Biochem. Biophys. Res. Commun. 209:760-767.

25. Poirier, F., P.M. Timmons, C.T. Chan, J.L. Guenet, and P.W. Rigby. 1992. Expression of the L14 lectin during mouse embryogenesis suggests multiple roles during pre- and post-implantation development. Development (Camb.). 115:143-155.

26. Cherayil, B.J., S.J. Weiner, and S. Pillai. 1989. The Mac-2 antigen is a galactose-specific lectin that binds IgE. J. Exp. Med. 170:1959-1972.

27. Sato, S., and R.C. Hughes. 1992. Binding specificity of a baby hamster kidney lectin for $\mathrm{H}$ type I and II chains, polylactosamine glycans, and appropriately glycosylated forms of laminin and fibronectin. J. Biol. Chem. 267:69836990.

28. Frigeri, L.G., M.W. Robertson, and F. Liu. 1990. Expression of biologically active recombinant rat IgE-binding protein in E. coli. J. Biol. Chem. 265: 20763-20769.

29. Yamaoka, A., I. Kuwabara, L.G. Frigeri, and F.T. Liu. 1995. A human lectin, galectin-3 ( $\epsilon \mathrm{bp} / \mathrm{Mac}-2)$, stimulates superoxide production by neutrophils. J. Immunol. 154:3479-3487.

30. Dagher, S.F., J.L. Wang, and R.J. Patterson. 1995. Identification of galectin-3 as a factor in pre-mRNA splicing. Proc. Natl. Acad. Sci. USA. 92:12131217.
31. Yang, R.Y., D.K. Hsu, and F.T. Liu. 1996. Expression of galectin-3 modulates T-cell growth and apoptosis. Proc. Natl. Acad. Sci. USA. 93:6737-6742.

32. Inohara, H., and A. Raz. 1995. Functional evidence that cell surface galectin-3 mediates homotypic cell adhesion. Cancer Res. 55:3267-3271.

33. Ochieng, J., R. Fridman, P. Nangia-Makker, D.E. Kleiner, L.A. Liotta, W.G. Stetler-Stevenson, and A. Raz. 1994. Galectin-3 is a novel substrate for human matrix metalloproteinases-2 and -9. Biochemistry. 33:14109-14114.

34. Mehul, B., S. Bawumia, and R.C. Hughes. 1995. Cross-linking of galectin-3 a galactose-binding protein of mammalian cells, by tissue-type transglutaminase. FEBS Lett. 360:160-164.

35. Wada, J., A. Kumar, Z. Liu, E. Ruoslahti, L. Reichardt, J. Marvaldi, and Y.S. Kanwar. 1996. Cloning of mouse integrin $\alpha_{\mathrm{V}} \mathrm{cDNA}$ and role of $\alpha_{\mathrm{V}}$-related matrix receptors in metanephric development. J. Cell Biol. 132:1161-1176.

36. Engvall, E., and P. Perlman. 1971. Enzyme-linked immunosorbent assay (ELISA). Quantitative assay of immunoglobulin G. Immunochemistry. 8:871874

37. Karen, D.F., and J.F. Warren. 1992. Ligand immunoassays. In Diagnostic Immunology. Williams \& Wilkins, Baltimore. 291-306.

38. Towbin, H., T. Staehelin, and J. Gordon. 1979. Electrophoretic transfer of proteins from polyacrylamide gels to nitrocellulose sheets: procedure and some applications. Proc. Natl. Acad. Sci. USA. 76:4350-4354.

39. Seglen, P.O. 1976. Preparation of isolated rat liver cells. Methods Cell Biol. 13:29-83.

40. Gavrieli, Y., Y. Sherman, and S.A. Ben-Sasson. 1992. Identification of programmed cell death in situ via specific labeling of nuclear DNA fragmentation. J. Cell Biol. 119:493-501.

41. Sgonc, R., G. Boeck, H. Dietrich, J. Gruber, H. Recheis, and G. Wick. 1994. Simultaneous determination of cell surface antigen and apoptosis. Trends Genet. 10:41-42.

42. Cooper, D.N.W., and S.H. Barondes. 1990. Evidence for export of a muscle lectin from cytosol to extracellular matrix and for a novel secretory mechanism. J. Cell Biol. 110:1681-1691.

43. Chinnaiyan, A.M., and V.M. Dixit. 1996. The cell-death machine. Curr. Biol. 6:555-562.

44. Shortman, K., D. Vremec, and M. Egerton. 1991. The kinetics of T-cell antigen receptor expression by subgroups of $\mathrm{CD} 4^{+} \mathrm{CD}^{+}$thymocytes: delineation of $\mathrm{CD}^{+} 8^{+} 3^{2+}$ thymocytes as post-selection intermediates leading to mature T cells. J. Exp. Med. 173:323-332.

45. Patel, D.D., and B.F. Hayes. 1993. Cell adhesion molecules involved in intrathymic T cell development. Semin. Immunol. 5:282-292.

46. Yin, X.M., Z.N. Oltvai, and S.J. Korsmeyer. 1994. BH1 and BH2 domains of $\mathrm{Bcl} 2$ are required for inhibition of apoptosis and heterodimerization with Bax. Nature (Lond.). 369:321-323.

47. Hanada, M., C. Aime-Sempe, T. Sato, and J.C. Reed. 1995. Structurefunction analysis of Bcl-2 protein. J. Biol. Chem. 270:11962-11969.

48. Hébert, E., and M. Monsigny. 1993. Oncogenes and expression of endogenous lectins and glycoconjugates. Biol. Cell. 79:97-109.

49. Hsu, D.K., S.R. Hammes, I. Kuwabara, W.C. Greene, and F.T. Liu. 1996. Human T lymphotropic virus-I infection of human T lymphocytes induces expression of the $\beta$-galactoside-binding lectin, galectin-3. Am. J. Pathol. 148: $1661-1670$.

50. Ong, C.J., D. Chui, H.S. Teh, and J.D. Marth. 1994. Thymic CD45 tyrosine phosphatase regulates apoptosis and MHC-restricted negative selection. J. Immunol. 152:3793-3805. 